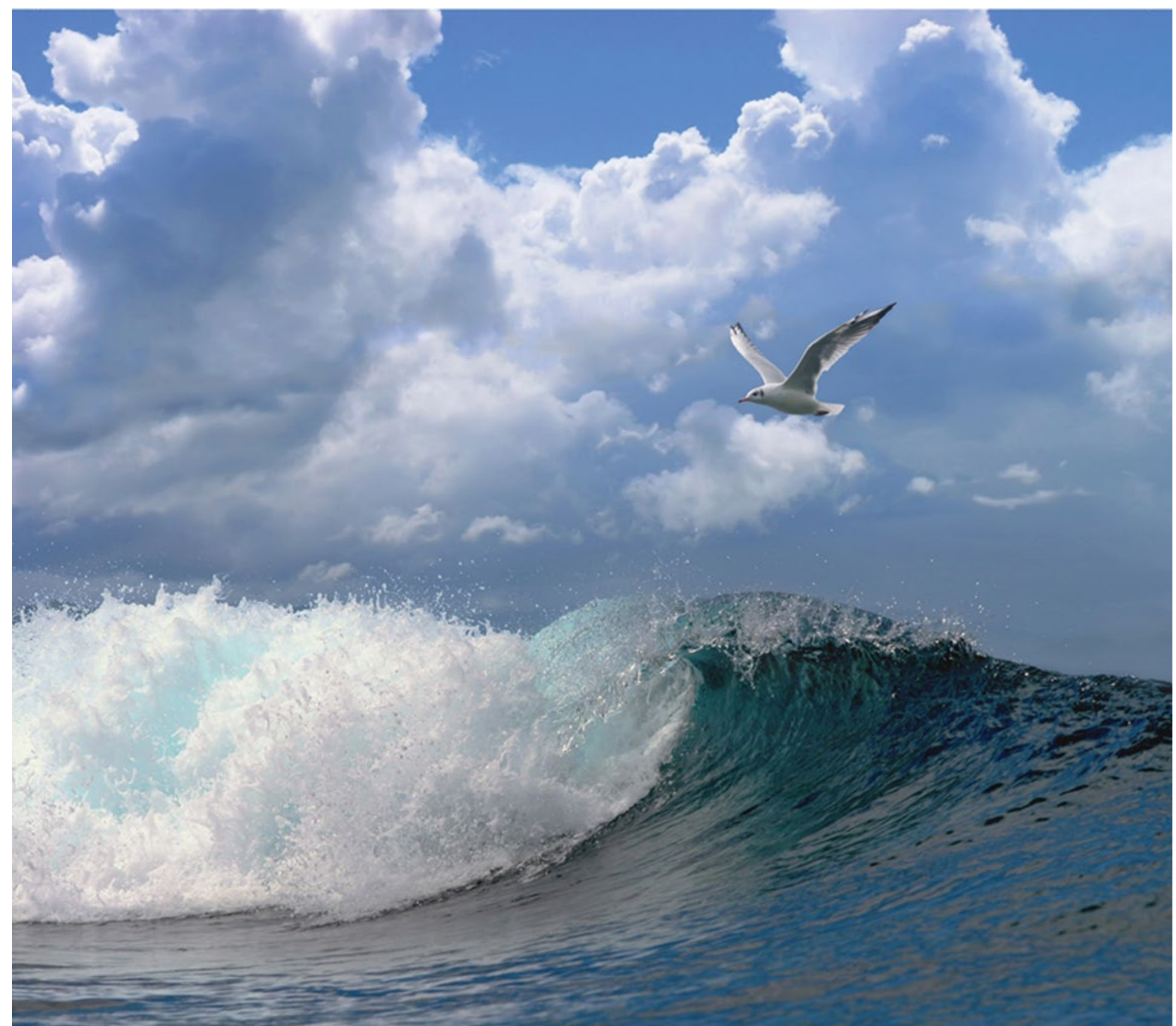

\title{
Garnalenvisserij in Natura 2000 gebieden
}




\section{Garnalenvisserij in Natura 2000 gebieden}

Auteur(s): Niels Hintzen

Wageningen Marine Research 
Keywords: Garnalenvisserij, Natura 2000, VMS, Logboek.

Dit rapport is gratis te downloaden van https://doi.org/10.18174/541762

Wageningen Marine Research verstrekt geen gedrukte exemplaren van rapporten.

Wageningen Marine Research is ISO 9001:2015 gecertificeerd.

\section{(C) Wageningen Marine Research}

Wageningen Marine Research, instituut binnen de rechtspersoon Stichting Wageningen Research, hierbij vertegenwoordigd door Dr. ir. J.T. Dijkman, managing director

KvK nr. 09098104,

WMR BTW nr. NL 8113.83.696.B16.

Code BIC/SWIFT address: RABONL2U

IBAN code: NL 73 RABO 0373599285
Wageningen Marine Research aanvaardt geen aansprakelijkheid voor gevolgschade, noch voor schade welke voortvloeit uit toepassingen van de resultaten van werkzaamheden of andere gegevens verkregen van Wageningen Marine Research. Opdrachtgever vrijwaart Wageningen Marine Research van aanspraken van derden in verband met deze toepassing.

Alle rechten voorbehouden. Niets uit deze uitgave mag weergegeven en/of gepubliceerd worden, gefotokopieerd of op enige andere manier gebruikt worden zonder schriftelijke toestemming van de uitgever of auteur. 


\section{Inhoud}

$1 \quad$ Samenvatting $\quad 4$

$2 \quad$ Inleiding $\quad \mathbf{5}$

3 Methoden $\quad 6$

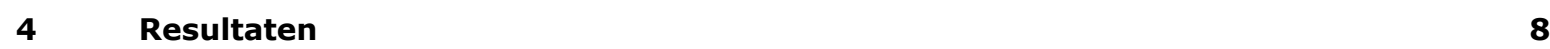

4.1 Visuren in de Natura 2000 gebieden $\quad 8$

4.2 Visuren met andere aannames over vissnelheid $\quad 10$

4.3 Dekking van VMS versus Logboeken 11

4.4 Visuren binnen en buiten de Natura 2000 gebieden $\quad 13$

$5 \quad$ Conclusies en aanbevelingen $\quad 15$

$\begin{array}{llr}6 & \text { Kwaliteitsborging } & 16\end{array}$

$\begin{array}{llr}7 & \text { Referenties } & 17\end{array}$

$\begin{array}{lr}\text { Verantwoording } & 18\end{array}$

Annex 1 - maandcijfers visuren $r$ 


\section{$1 \quad$ Samenvatting}

De Nederlandse garnalenvisserij vindt plaats langs de gehele Nederlandse, Duitse en Deense westkust. In het afgelopen decennium is de inzet van deze visserij fors toegenomen. Een deel van deze visserij vindt plaats binnen Natura 2000 gebieden; de garnalenvisserij is binnen die gebieden gereguleerd onder de Wet natuurbescherming. Deze gebieden zijn de Noordzeekustzone, Vlakte van de Raan, Voordelta, Waddenzee, Westerschelde en Oosterschelde. De vergunde garnalenvisserij intensiteit is beoordeeld op haar ecologische effecten aan de hand van een gesteld ijkjaar (2015). Visserijintensiteiten die boven dit ijkpunt uitkomen kunnen aanleiding geven tot heroverweging van die ecologische beoordeling. WMR monitort in opdracht van LNV de visserijintensiteit binnen de Natura 2000 gebieden om zodoende binnen een lopend jaar zicht te houden op de visserij-intensiteiten.

In dit rapport presenteren we de laatste getallen over het jaar 2020.

De resultaten laten een duidelijke toename in 2020 zien in vergelijking met de jaren 2018 en 2019 . In 2020 komt het aantal visuren in de Vlakte van de Raan ruim boven het ijkjaar uit, net zoals het geval was vanaf 2016. Ook in de Oosterschelde is dit het geval maar daar is de inspanning lager dan in de piekjaren in 2016 en 2017. In de Noordzee kustzone komt het aantal visuren net boven het ijkjaar uit waarbij de Waddenzee en Westerschelde net onder de inspanning uit het ijkjaar blijven. Er is een duidelijke seizoenstrend met vooral visserij rondom de zomermaanden met uitzondering van de Oosterschelde waar in de maand december veel uren zijn gemaakt.

Overige berekende indicatoren over de visserij, zoals de snelheid waarmee gevist word, alsook de dekking tussen visuren berekent met behulp van VMS en de logboeken en waargenomen maandtrends laten geen ander beeld zien dan in de jaren daarvoor gerapporteerd werd. 


\section{$2 \quad$ Inleiding}

De garnalenvisserij vindt plaats langs de gehele Nederlandse, Duitse en Deense westkust. In het afgelopen decennium is de inzet van deze visserij fors toegenomen (agrimatie.nl). Een deel van deze visserij vindt plaats binnen Natura 2000 gebieden; de garnalenvisserij is binnen die gebieden gereguleerd onder de Wet natuurbescherming (hierna: Wnb). Deze gebieden zijn de Noordzeekustzone, Vlakte van de Raan, Voordelta, Waddenzee, Westerschelde en Oosterschelde (zie ook Figuur 1). De vergunde garnalenvisserij intensiteit is beoordeeld op haar ecologische effecten aan de hand van een gesteld ijkjaar (2015). Visserijintensiteiten die boven dit ijkpunt uitkomen kunnen aanleiding geven tot heroverweging van die ecologische beoordeling. WMR monitort in opdracht van LNV de visserijintensiteit binnen de Natura 2000 gebieden om zodoende binnen een lopend jaar zicht te houden op de visserij-intensiteiten.

In deze rapportage word de inzet in visuren (het aantal uren van vissende activiteit) bepaald voor de verschillende Natura 2000 gebieden voor de jaren 2013-2020.

Daartoe worden VMS en logboekgegevens van de visserij geanalyseerd en een berekening gemaakt van vissende activiteit.

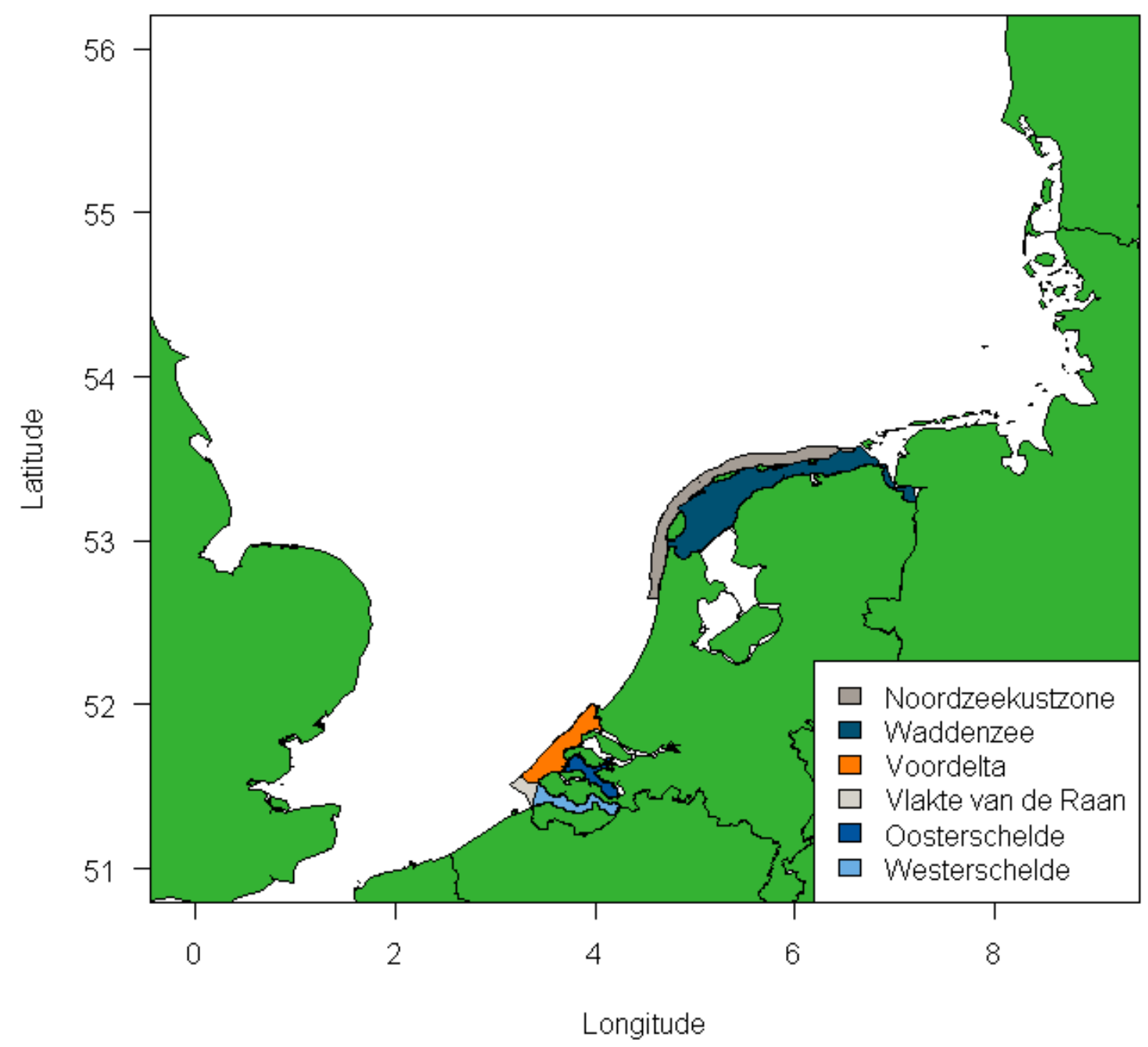

Figuur 1. Natura 2000 gebieden die van belang zijn voor garnalenvisserij. 


\section{Methoden}

\section{Bewerking gegevens}

Voor het bepalen van de indicatoren (visuren en vangst) in deze studie zijn verschillende gegevensbronnen gebruikt:

- Vessel Monitoring System (VMS-gegevens over de positie en snelheid van de schepen)

- Logboekgegevens (visregistratie- en informatiesysteem, VIRIS) over de reis: visserij-inzet, tuig en vangst (zowel logboeken als officieel geregistreerde vangsten)

- Vlootgegevens van het Nederlandse register van Vissersvaartuigen (NRV) over de technische specificaties van de schepen

- Vergunninghouders, aangeleverd door het Ministerie van LNV; de in deze lijst regelmatig doorgevoerde mutaties zijn in de analyses meegenomen.

De drie eerstgenoemde gegevenssets zijn op een gestandaardiseerde manier geanalyseerd, conform de aanpak ontwikkeld door Hintzen et al., (2013).

Allereerst zijn de VMS-gegevens en logboekgegevens opgeschoond. VMS-records zijn verwijderd wanneer ze:

- duplicaten of pseudo-duplicaten zijn (VMS pings dichter in tijd bij elkaar dan waar de interval tijd op ingesteld staat (b.v. iedere $30 \mathrm{~min}$ of $120 \mathrm{~min}$ )

- $\quad$ niet gepositioneerd zijn op de wereldbol

- in een haven liggen

- op het land liggen

- geassocieerd zijn met vaartuigsnelheden > 20 mijl per uur.

Logboekrecords zijn verwijderd wanneer ze:

- duplicaten zijn

- een aankomsttijd vóór de vertrektijd hebben

- beginnen vóór 1 januari van het jaar dat wordt geanalyseerd (ook al valt het einde van de reis binnen het beschouwde jaar)

- $\quad$ overlap hebben met andere reizen van hetzelfde schip.

Om de visserijactiviteiten in de gebieden te analyseren, werden de ruimtelijke VMS-gegevens gekoppeld aan de inzet- en vangstgegevens uit de logboeken. VMS- en logboekgegevenssets werden gekoppeld met behulp van het schipnummer en de datum en tijd. Alle VMS-records (ook wel 'pings' genoemd) die tussen de tijd van vertrek en tijd van aankomst van een reis in het logboek vallen, werden toegewezen aan de betreffende reis. Vervolgens werd voor elk VMS-record de activiteit van het vaartuig (halen, vissen of stomen) bepaald op basis van de snelheid en het type visserij (zie ook Poos et al., 2013), alsook werd er met een vaste snelheidsregel gewerkt waarbij werd aangenomen dat een schip vissend is wanneer deze harder dan 0.1 maar minder hard dan 5.5 knopen vaart. Deze karakterisering werd gebaseerd op een analyse van de frequentieverdelingen van vaarsnelheden van alle VMS-records voor het betreffende tuig. Ook alternatieve snelheidsprofielen zijn uitgetest om de gevoeligheid van de rekenmethode te toetsen.

Elke VMS-ping vertegenwoordigt een bepaalde tijdsduur. Deze is gewoonlijk gelijk aan de intervalsnelheid waarmee VMS-pings worden uitgezonden, variërend van 30 minuten tot 2 uur. De visserij-inzet werd gedefinieerd als de som van deze tijdstappen voor de pings die als vissen geclassificeerd waren zodat het aantal visuren verkregen werd. De aanlandingen (vangst) worden geregistreerd per reis, per ICES-rechthoek en dag in het logboek. Alleen visreizen waarin garnalenvangst werd aangeland zijn meegenomen in deze analyse. 


\section{Vergunninghouders}

Door het ministerie van LNV zijn scheepsnamen aangeleverd die een Wnb-vergunning hadden tussen de jaren 2016 en 2020. Voor jaren voorafgaand aan 2016 zijn die schepen meegenomen in de analyse die in 2016 een vergunning kregen toegewezen. Voor de jaarlijkse monitoring beschikt WMR vanuit het ministerie van LNV over de lijst van vergunninghouders en de daarop doorgevoerde mutaties (bijvoorbeeld bij het omnummeren van een vaartuig). De monitoring volgt daarmee 'real time' de op elk moment geldende situatie qua groep van vergunninghouders.

Visuren binnen en buiten Natura 2000 gebieden

Shapefiles van de Natura 2000 gebieden zijn aangeleverd door het ministerie van LNV. Op basis van die gegevens is bekeken welke VMS-pings binnen en welke buiten deze gebieden vielen. Indien pings binnen deze gebieden vielen, werden ze meegenomen in de analyse om visuren binnen de gebieden te berekenen. 


\section{$4 \quad$ Resultaten}

\subsection{Visuren in de Natura 2000 gebieden}

Op basis van een vast snelheidsprofiel (tussen $0.1-5.5$ knopen) is het geschatte aantal visuren gegeven in de tabel 1 hieronder. Getallen geven alleen geschatte vissende activiteit weer en niet andere vormen van activiteit zoals stomen. Het ijkjaar (2015) is schuingedrukt voor extra nadruk.

Tabel 1 Geschatte aantal visuren per jaar en gebied.

\begin{tabular}{|l|r|r|r|r|r|r|r|r|} 
& $\mathbf{2 0 1 3}$ & $\mathbf{2 0 1 4}$ & $\mathbf{2 0 1 5}$ & $\mathbf{2 0 1 6}$ & $\mathbf{2 0 1 7}$ & $\mathbf{2 0 1 8}$ & $\mathbf{2 0 1 9}$ & $\mathbf{2 0 2 0}$ \\
\hline Oosterschelde (OO) & 0 & 73 & 292 & 2127 & 1474 & 523 & 124 & 944 \\
\hline Westerschelde (WE) & 2578 & 1807 & 3594 & 6401 & 6520 & 4375 & 2884 & 3226 \\
\hline $\begin{array}{l}\text { Noordzee kustzone } \\
\text { (NO) }\end{array}$ & 117503 & 150258 & 120867 & 150855 & 87081 & 108469 & 97645 & 126878 \\
\hline $\begin{array}{l}\text { Voordelta (VO) } \\
\text { Vlakte van de Raan }\end{array}$ & 18016 & 18607 & 25565 & 28067 & 28176 & 16112 & 16837 & 18810 \\
\hline $\begin{array}{l}\text { (VL) } \\
\text { Waddenzee (WA) }\end{array}$ & 3622 & 3276 & 3644 & 4659 & 4350 & 4268 & 3714 & 5287 \\
\hline
\end{tabular}
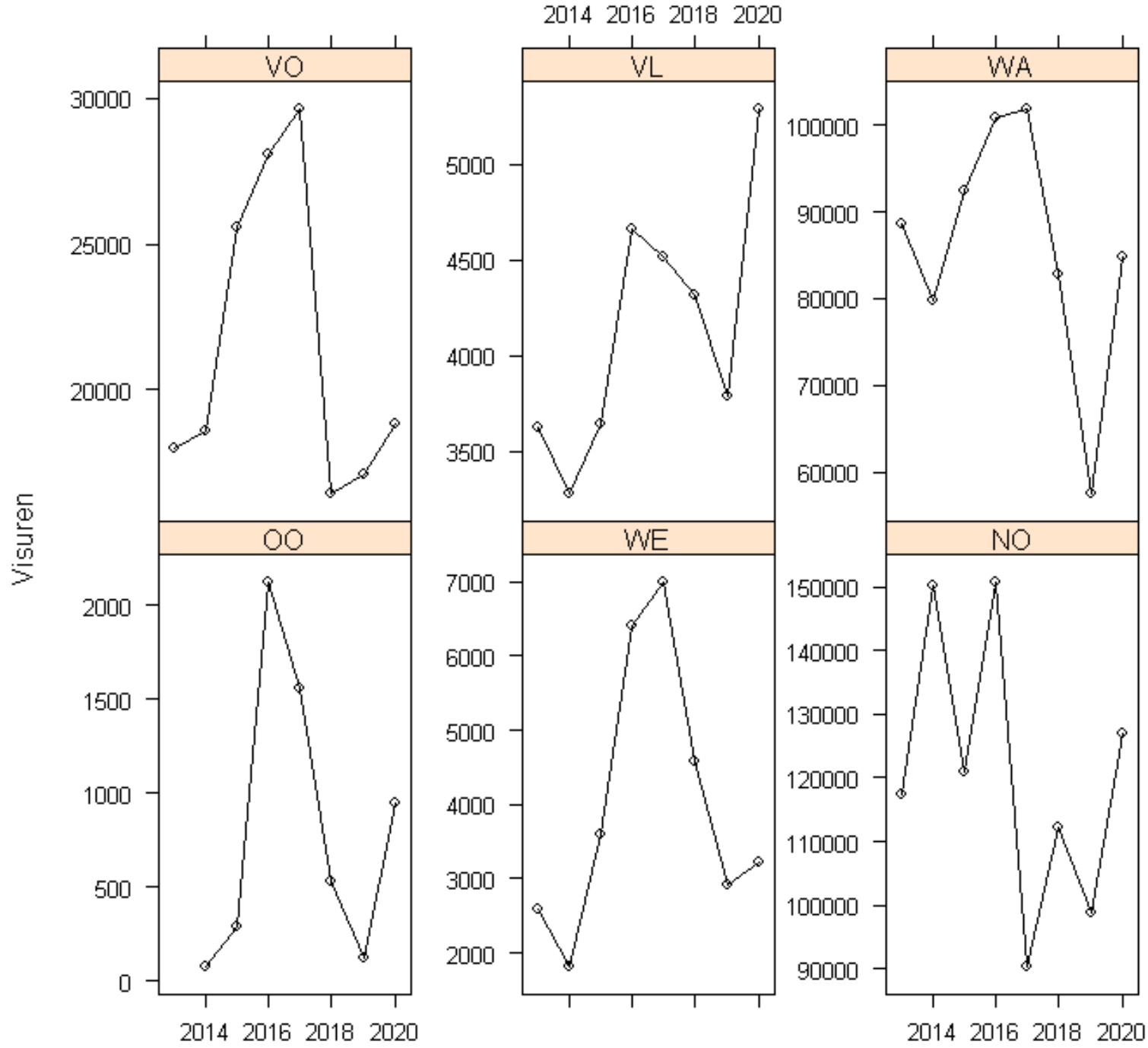

Jaren

Figuur 2. Geschatte visuren ontwikkeling binnen de zes Natura 2000 gebieden. 
De visserij op garnalen is sterk wisselend per maand (Figuur 3), de maandelijkse geschatte visserijinspanning in ieder van de zes gebieden is in de figuur hieronder weergegeven. In veel gevallen is het aantal visuren in de laatste jaren gedaald ten opzichte van het ijkjaar 2015, zie Figuur 2.

De resultaten laten een duidelijke toename in 2020 zien in vergelijking met de jaren 2018 en 2019 . In 2020 komt het aantal visuren in de Vlakte van de Raan ruim boven het ijkjaar uit, net zoals het geval was vanaf 2016. Ook in de Oosterschelde is dit het geval maar daar is de inspanning lager dan in de piekjaren in 2016 en 2017. In de Noordzee kustzone komt het aantal visuren net boven het ijkjaar uit waarbij de Waddenzee en Westerschelde net onder de inspanning uit het ijkjaar blijven. Er is een duidelijke seizoenstrend met vooral visserij rondom de zomermaanden met uitzondering van de Oosterschelde waar in de maand december veel uren zijn gemaakt. De toe/afnames zijn procentueel weergegeven in tabel 2.
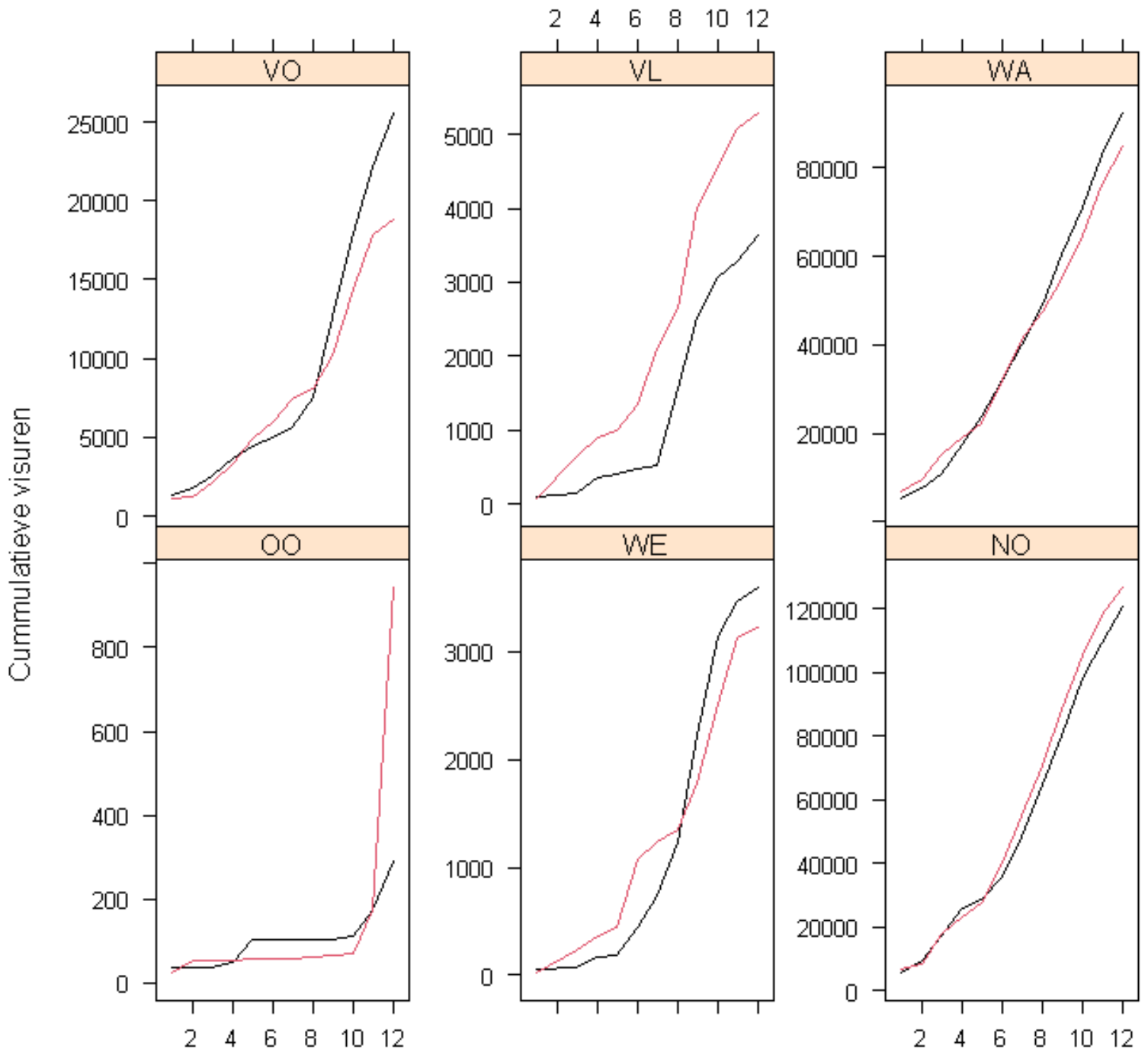

Maanden

Figuur 3. Geschatte cummulatieve visuren per Natura 2000 gebied (panelen, in rood) per maand aan de hand van de 0.1-5.5 knopen snelheidsregel ten opzichte van het ijkjaar 2015 (in zwart). 
Tabel 2. Percentage toename of afname per Natura2000 gebied ten opzichte van het ijkjaar 2015

2015

2016

2017

2018

2019

2020

\begin{tabular}{|c|c|c|c|c|c|c|}
\hline Oosterschelde (OO) & - & 628 & 405 & 79 & -58 & 223 \\
\hline Westerschelde (WE) & - & 78 & 81 & 22 & -20 & -10 \\
\hline $\begin{array}{r}\text { Noordzee kustzone } \\
\text { (NO) }\end{array}$ & - & 25 & -28 & -10 & -19 & 5 \\
\hline Voordelta (VO) & - & 10 & 10 & -37 & -34 & -26 \\
\hline $\begin{array}{r}\text { Vlakte van de Raan } \\
\text { (VL) }\end{array}$ & - & 28 & 19 & 17 & 2 & 45 \\
\hline Waddenzee (WA) & - & 9 & 5 & -14 & -39 & -8 \\
\hline
\end{tabular}

\subsection{Visuren met andere aannames over vissnelheid}

Welke vaarsnelheden aangemerkt worden als vissend heeft een impact op de uitkomsten van geschatte vissende activiteit binnen de Natura 2000 gebieden. Immers, bij een grotere range in vissnelheid neemt het aantal geschatte visuren toe. Figuur 4 geeft aan wat de orde-grote verschillen zijn tussen de modellen per Natura 2000 gebied.

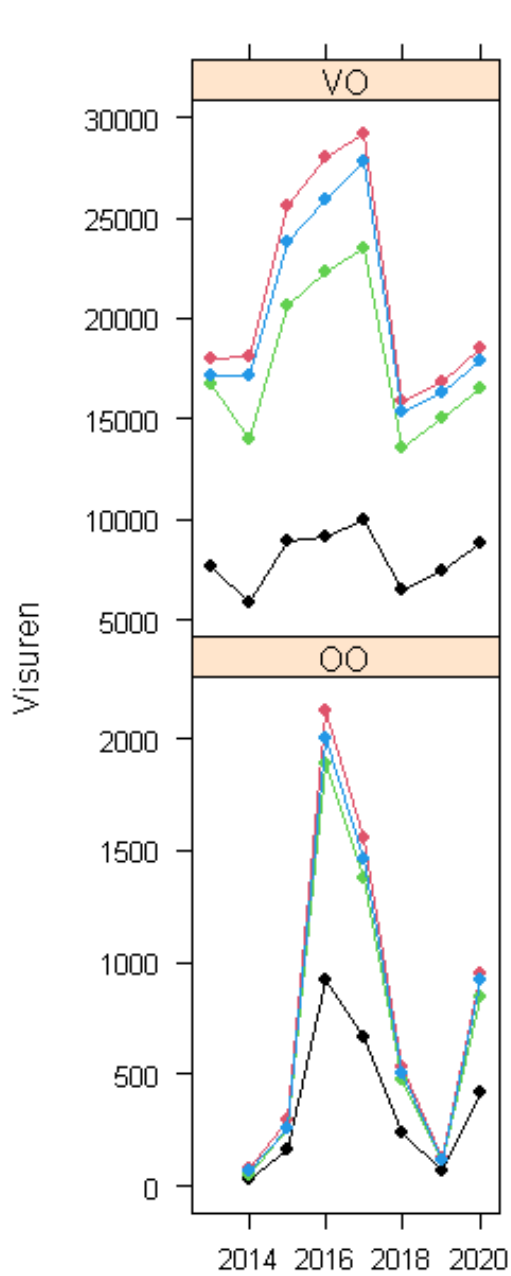

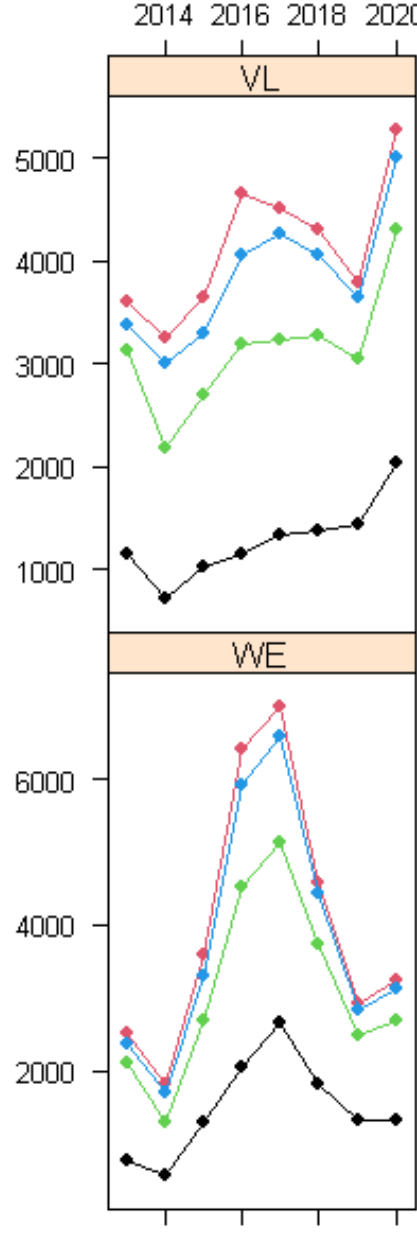

Jaren

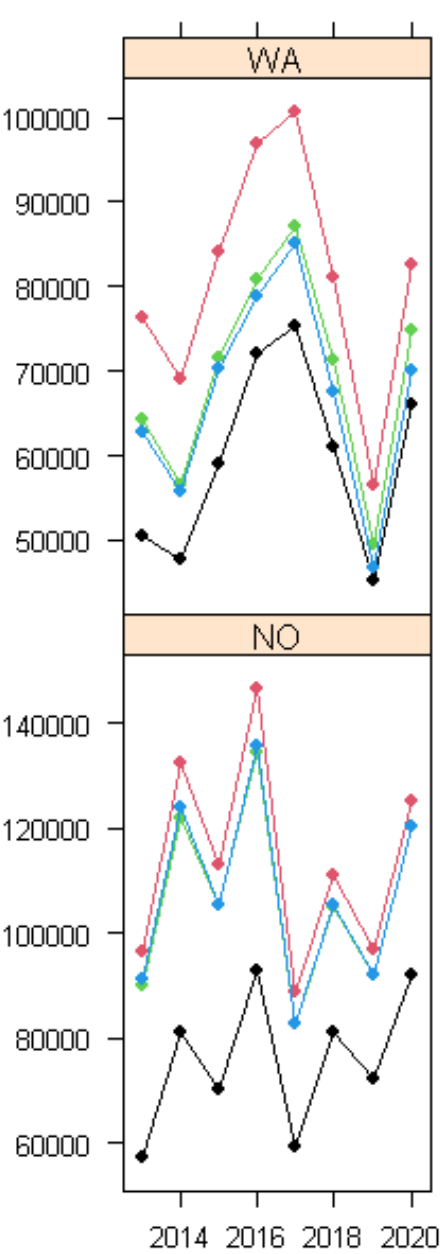

Figuur 4. Geschatte visuren aan de hand van 4 verschillende snelheidsprofielen. In rood het model waarbij snelheden tussen 0.1-5.5 knopen als vissend worden beschouwd (het basis model zoals in paragraaf 3.1 gerapporteerd), in blauw het model waarbij een statistisch model, apart gefit voor 10 verschillende garnalengebieden gebruikt is, in groen het model waarbij een enkel statistisch model voor het hele verspreidingsgebied genomen is, in zwart het model waarbij snelheden tussen 0.1-3 knopen als vissend worden beschouwd. 
Wanneer deze lijnen relatief ten opzichte van het basis model (0.1-5.5 knopen) worden bekeken (Figuur 5) zien we dat alle overige modellen een lagere schatting van visuren geven. De verschillen met het 0.1-3 knopen model zijn daarin het grootst en de verschillen met de twee statistische modellen ligt tussen de 5-20\%.

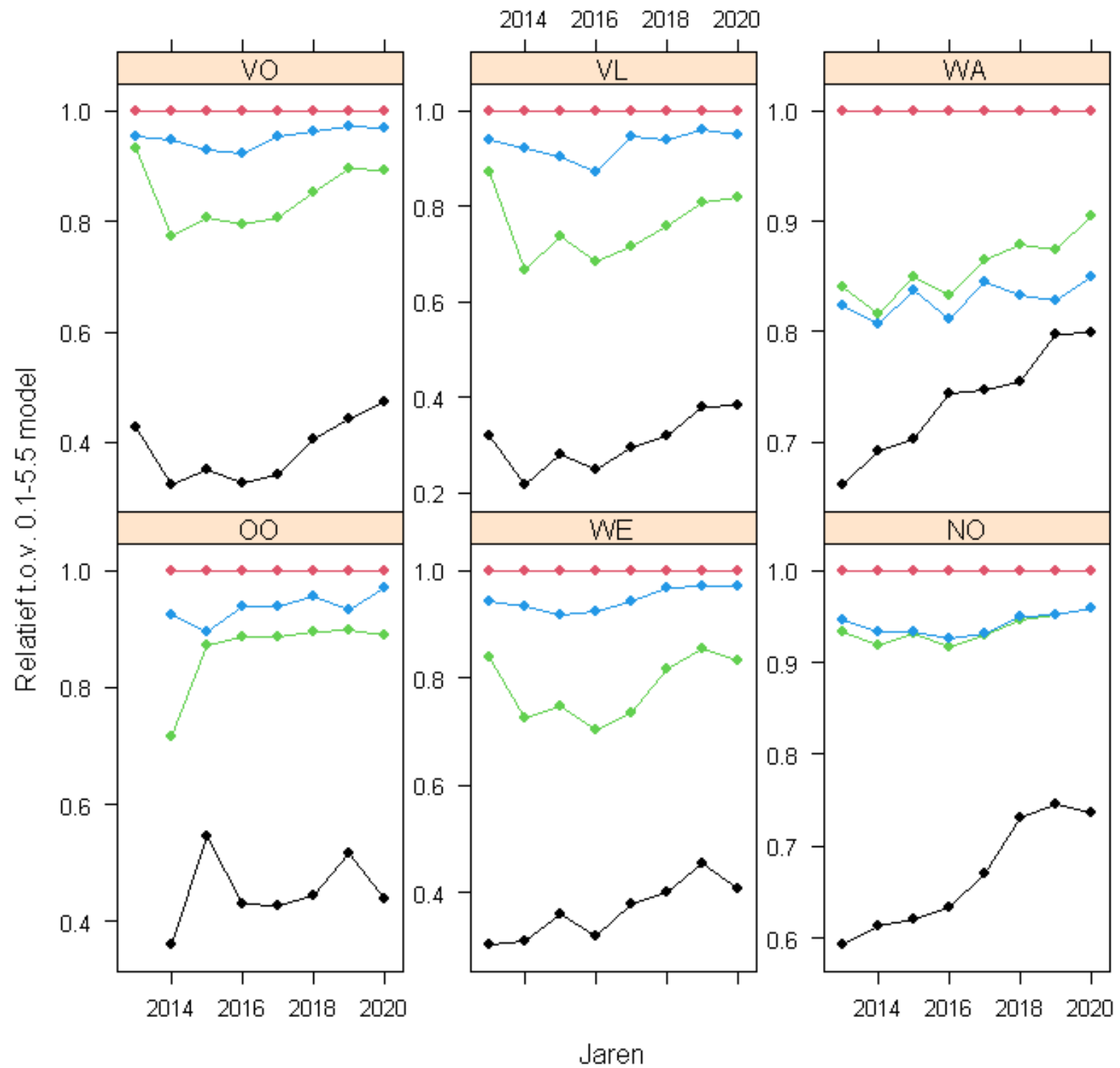

Figuur 5. Ratio tussen geschatte visuren tussen het basismodel en 3 alternatieve modellen. In rood het basismodel (ratio $=1$ ), in rood het 0.1-3 knopen model, in groen het enkel gebied statistisch model en in blauw het model met 10 verschillende visgebieden verwerkt.

\subsection{Dekking van VMS versus Logboeken}

In de logboeken wordt opgeschreven op welke tijd uit de haven vertrokken en weer binnengevaren wordt. In het geval van VMS worden alleen die pings meegenomen in de berekening van visuren wanneer deze binnen het interval van de logboeken vallen. Dat betekent dan ook dat op basis van VMS er altijd een lager aantal visuren geregistreerd zal zijn dan op basis van logboeken omdat VMS niet precies gelijk getimed is met vertrek of binnenkomst in de haven. Tabel 3 hieronder geeft de dekking van VMS in de logboeken weer. De getallen geven de totale aantallen uren dat vissers uit de haven zijn, berekend vanuit de logboeken als ook uit de VMS. Een getal van 100 in de rij 'Ratio' betekent dat er evenveel tijd uit de haven in VMS zit als in de logboeken. Een getal van 125 betekent dat er $25 \%$ meer tijd uit de haven in de logboeken geregistreerd is dan in VMS. 
Tabel 3. Geregistreerde uren in de logboeken en VMS, alsook de berekende ratio tussen de twee datasets.

\begin{tabular}{|l|l|l|l|l|l|l|l|l|} 
& $\mathbf{2 0 1 3}$ & $\mathbf{2 0 1 4}$ & $\mathbf{2 0 1 5}$ & $\mathbf{2 0 1 6}$ & $\mathbf{2 0 1 7}$ & $\mathbf{2 0 1 8}$ & $\mathbf{2 0 1 9}$ & $\mathbf{2 0 2 0}$ \\
\hline Logboeken & 22067 & 21054 & 20786 & 22928 & 20684 & 20113 & 13315 & 18676 \\
\hline VMS & 18312 & 19065 & 17669 & 21041 & 16465 & 19292 & 12500 & 18107 \\
\hline Ratio (Log/VMS) & 121 & 110 & 118 & 109 & 126 & 104 & 107 & 103 \\
\hline
\end{tabular}

Vanwege enkele uitschieters ligt het jaarlijks gemiddelde in 2017 boven de $25 \%$, voor de overige hier geanalyseerde jaren blijft het verschil onder de 25\% Maandgemiddeldes zijn weergegeven in Figuur 6 . Over de hele linie genomen, gecorrigeerd voor deze uitschieters door de mediaan in plaats van gemiddelde te nemen, ligt de gemeten effort van VMS 9\% lager dan die van de logboeken (Figuur 6). Op een gemiddelde visreis van 48 uur komt dat neer op 4 uur, net meer dan op basis van toeval te verwachten is. Er is verder geen specifiek maandpatroon daarin weer te nemen.

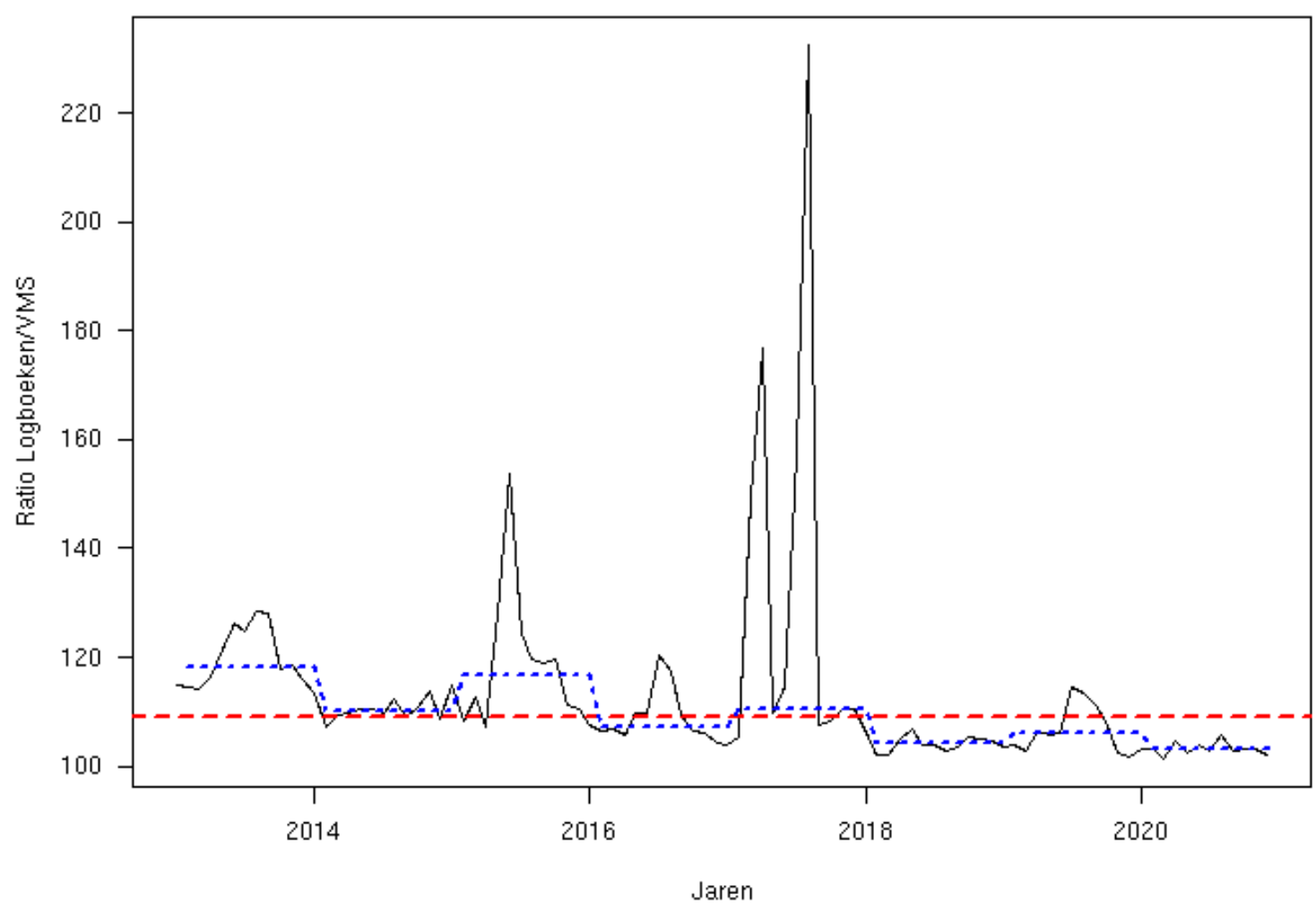

Figuur 6. Ratio tussen effort in logboeken versus die in VMS. Maandelijks gemiddelde is gegeven in de zwarte lijn. Het gemiddelde over de periode 2013-2020, gecorrigeerd voor de uitschieters, is gegeven met de rode lijn. Jaargemiddeldes staan aangegeven met de blauwe gestippelde lijn. Op de $y$-as staat de dekking waarbij 100 betekent dat 100\% van de logboek tijd uit de haven in VMS staat, 120 komt overeen met een $20 \%$ hogere tijd uit de haven in de logboeken ten opzichte van die in VMS.

Op scheepsniveau zien we een grote spreiding in de dekking. Figuur 7 geeft de dekking over alle visreizen per schip over de jaren 2013-2020 weer. Het overgrote deel heeft een dekking dicht in de buurt van de $100 \%$ lijn. Echter zien we ook grote uitschieters met maar een dekking tussen de $40-$ $60 \%$. 


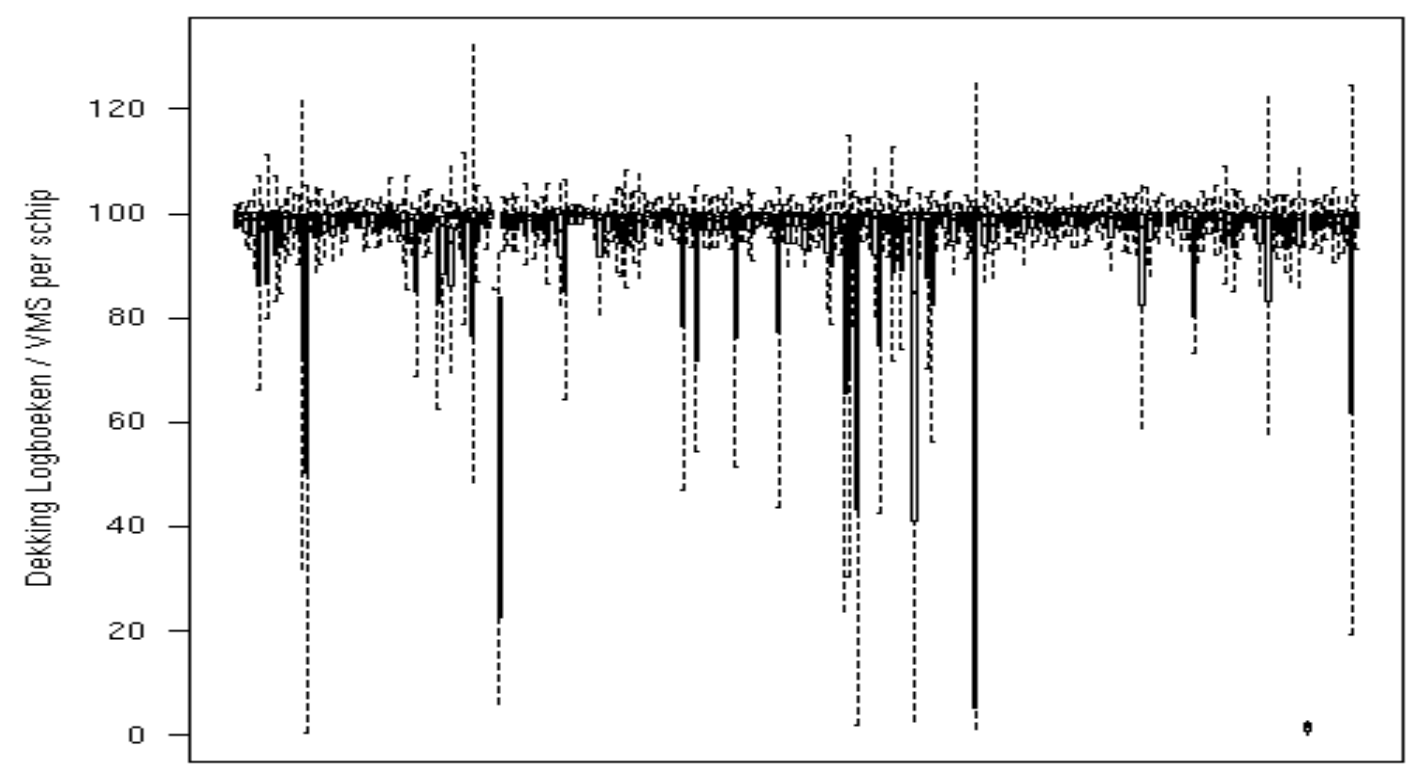

Figuur 7. Spreiding in dekking van alle visreizen per schip tussen 2013-2020. Op de y-as staat de dekking waarbij 100 betekent dat 100\% van de logboek tijd uit de havent in VMS staat, 120 komt overeen met een $20 \%$ hogere tijd uit de haven in de logboeken ten opzichte van die in VMS.

\subsection{Visuren binnen en buiten de Natura 2000 gebieden}

Het aantal visuren dat per jaar gerealiseerd wordt binnen Natura 2000 gebieden fluctueert tussen de $57 \%$ en $73 \%$ (zie tabel hieronder).

\begin{tabular}{|l|l|l|l|l|l|l|l|l|l|} 
& $\mathbf{2 0 1 3}$ & $\mathbf{2 0 1 4}$ & $\mathbf{2 0 1 5}$ & $\mathbf{2 0 1 6}$ & $\mathbf{2 0 1 7}$ & $\mathbf{2 0 1 8}$ & $\mathbf{2 0 1 9}$ & $\mathbf{2 0 2 0}$ \\
\hline $\begin{array}{l}\text { Buiten Natura } \\
\mathbf{2 0 0 0}\end{array}$ & 155907 & 136229 & 111210 & 131545 & 95590 & 166975 & 66139 & 129843 \\
$\begin{array}{l}\text { Binnen Natura } \\
\mathbf{2 0 0 0}\end{array}$ & 230414 & 253838 & 246352 & 292930 & 234803 & 220859 & 180280 & 239962 \\
\hline \begin{tabular}{l} 
Proportie binnen \\
\hline
\end{tabular} & 0.6 & 0.65 & 0.69 & 0.69 & 0.71 & 0.57 & 0.73 & 0.65 \\
\hline
\end{tabular}

Er zit een duidelijke maandtrend in het aandeel van de visserij binnen en buiten de Natura 2000 gebieden. In de zomermaanden word veel binnen de Natura 2000 gebieden gevist en richting december - januari zakt dat naar een minimum. In de wintermaanden is de tijd uit de haven ook op het laagste punt waardoor visuren binnen Natura 2000 gebieden minimaal uitkomen (Figuur 8). 


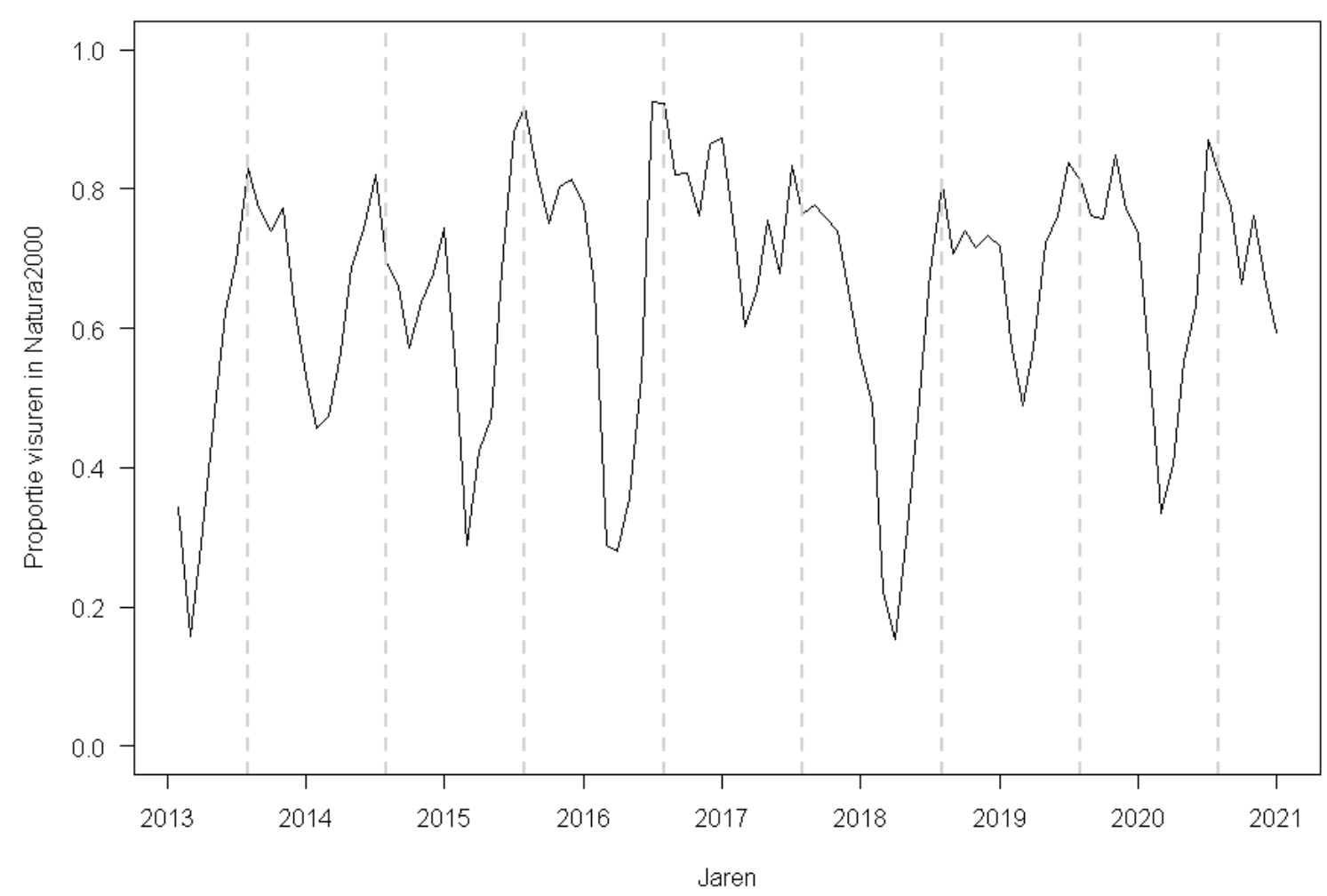

Figuur 8. Proportie van de visuren binnen de Natura 2000 gebieden ten opzichte van de hele vlootinzet. De verticale stippellijntjes geeft de maand juli weer waarin veelal de piek bereikt wordt in aandeel. 


\section{$5 \quad$ Conclusies en aanbevelingen}

Deze studie geeft inzicht in het aantal visuren van garnalenkotters, berekend op basis van VMS, binnen de Natura 2000 gebieden. De resultaten laten een duidelijke toename in 2020 zien in vergelijking met de jaren 2018 en 2019. In 2020 komt het aantal visuren in de Vlakte van de Raan ruim boven het ijkjaar uit, net zoals het geval was vanaf 2016 . Ook in de Oosterschelde is dit het geval maar daar is de inspanning lager dan in de piekjaren in 2016 en 2017. In de Noordzee kustzone komt het aantal visuren net boven het ijkjaar uit waarbij de Waddenzee en Westerschelde net onder de inspanning uit het ijkjaar blijven. Er is een duidelijke seizoenstrend met vooral visserij rondom de zomermaanden met uitzondering van de Oosterschelde waar in de maand december veel uren zijn gemaakt.

In deze studie spreken we van geschatte visuren, omdat niet met zekerheid te stellen is dat een visser daadwerkelijk gevist heeft, maar dat het alleen aannemelijk is, gegeven een bepaalde vaarsnelheid, dat de visser vissende was. De manier waarop snelheid vertaald wordt naar vissende activiteit hangt zodoende af van aannames. Zo kan er een vaste snelheidsgrens genomen worden waarboven / waaronder we aannemen dat er gevist wordt of er kan met behulp van statistische modellen en de frequentie van gemeten snelheden bepaald worden of er gevist wordt of niet. In deze studie zijn 2 vaste snelheidsgrenzen en 2 statistische modellen getoetst. Hieruit blijkt dat er langs de Nederlandse kust in verschillende gebieden ook met andere vissnelheden gevist wordt (zie het 10-gebieds statistisch model), immers, het model met 10 sub-gebieden laat een andere trend zien dan die van 1gebied. Het nemen van een snelheidsprofiel waarbij boven 0.1 en onder 5.5 knopen ervanuit gegaan word dat een schip vissende is, blijkt de meest ruime maat te zijn van al de hier geteste varianten.

Op dit moment is VMS het enige middel om te toetsen of vissers actief waren binnen Natura 2000 gebieden. Echter, het is bekend dat VMS veelal een lagere inschatting geeft van het aantal visuren dan wanneer dit op basis van logboeken zou worden bepaald. Belangrijk hierbij op te merken is dat de visuren op basis van VMS berekend, uitgaan van vissende activiteit, terwijl visuren bepaald op basis van logboeken uitgaan van het uit de haven zijn van een vissersschip. De lagere inschatting van visuren is ook te wijten aan het missen van VMS pings gedurende een visreis. Veelal is dit gering, maar in een aantal gevallen zijn er schepen die wel $>60 \%$ van de VMS pings missen binnen een visreis. Dit zorgt voor een onderschatting van het werkelijke aantal visuren. Er is echter niet tot nauwelijks een trend waarneembaar in deze onderschatting over de jaren heen, waarmee de VMS als relatieve maat genomen kan worden. Indien de onderschatting afneemt in toekomstige jaren dient deze relatieve maat wel herzien te worden.

Een aanzienlijk deel van de garnalenvisserij vindt plaats binnen de Natura 2000 gebieden, tot wel $70 \%$ in de zomermaanden. Dit betekent ook dat minimaal 30\% van de visserij daarbuiten plaatsvindt. Dit geeft dan ook aan dat garnalenvisserij niet exclusief is toebehouden aan de Natura 2000 gebieden. 


\section{$6 \quad$ Kwaliteitsborging}

Wageningen Marine Research beschikt over een ISO 9001:2015 gecertificeerd

kwaliteitsmanagementsysteem. Dit certificaat is geldig tot 15 december 2021. De organisatie is gecertificeerd sinds 27 februari 2001. De certificering is uitgevoerd door DNV GL. 


\section{$7 \quad$ Referenties}

Hintzen, N.T. Coers, A., Hamon, K. (2013) A collaborative approach to mapping value of fisheries resources in the North Sea (Part 1: Methodology). http://edepot.wur.nl/248628 


\section{Verantwoording}

Rapport C013/21

Projectnummer: 4316100203

Dit rapport is met grote zorgvuldigheid tot stand gekomen. De wetenschappelijke kwaliteit is intern getoetst door een collega-onderzoeker en het verantwoordelijk lid van het managementteam van Wageningen Marine Research

Akkoord:

S.T. Glorius

Collega-onderzoeker

Handtekening:

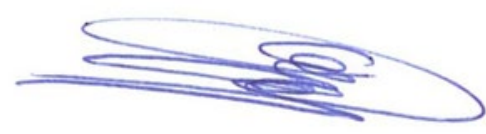

Datum:

17 februari 2021

Akkoord:

Dr. Ir. T.P. Bult

Director

Handtekening:

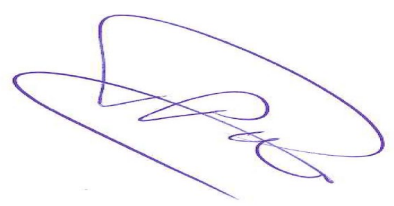

Datum:

17 februari 2021 


\section{Annex 1 - maandcijfers visuren}

\section{Oosterschelde}

\begin{tabular}{|r|r|r|r|r|r|r|r|r|r|r|r|r|r|}
\hline & Jan & Feb & Maa & Apr & Mei & Jun & Jul & Aug & Sep & Okt & Nov & Dec \\
\hline 2013 & 0 & 0 & 0 & 0 & 0 & 0 & 0 & 0 & 0 & 0 & 0 & 0 \\
\hline 2014 & 3 & 2 & 0 & 0 & 17 & 5 & 1 & 6 & 1 & 2 & 2 & 35 \\
\hline 2015 & 36 & 1 & 0 & 14 & 51 & 0 & 1 & 0 & 3 & 7 & 63 & 116 \\
\hline 2016 & 66 & 7 & 5 & 2 & 1 & 30 & 201 & 437 & 306 & 295 & 321 & 455 \\
\hline 2017 & 272 & 25 & 1 & 0 & 59 & 134 & 303 & 5 & 20 & 73 & 371 & 295 \\
\hline 2018 & 310 & 24 & 0 & 0 & 35 & 23 & 110 & 4 & 13 & 10 & 0 & 0 \\
\hline 2019 & 30 & 1 & 1 & 0 & 0 & 16 & 8 & 0 & 0 & 2 & 41 & 27 \\
\hline 2020 & 23 & 32 & 0 & 0 & 0 & 0 & 4 & 2 & 0 & 11 & 104 & 769 \\
\hline
\end{tabular}

\section{Westerschelde}

\begin{tabular}{|r|r|r|r|r|r|r|r|r|r|r|r|r|r|}
\hline & Jan & Feb & Maa & Apr & Mei & Jun & Jul & Aug & Sep & Okt & Nov & Dec \\
\hline 2013 & 0 & 2 & 0 & 139 & 93 & 76 & 98 & 403 & 462 & 681 & 489 & 135 \\
\hline 2014 & 15 & 0 & 2 & 0 & 10 & 93 & 118 & 116 & 451 & 470 & 381 & 152 \\
\hline 2015 & 52 & 0 & 14 & 95 & 26 & 263 & 282 & 500 & 991 & 907 & 336 & 127 \\
\hline 2016 & 43 & 3 & 0 & 110 & 153 & 1662 & 481 & 748 & 944 & 1017 & 947 & 292 \\
\hline 2017 & 39 & 1 & 176 & 40 & 249 & 1483 & 348 & 80 & 1226 & 2440 & 736 & 181 \\
\hline 2018 & 35 & 0 & 15 & 263 & 892 & 1612 & 151 & 211 & 641 & 539 & 179 & 38 \\
\hline 2020 & 9 & 0 & 17 & 165 & 138 & 149 & 37 & 167 & 668 & 924 & 507 & 141 \\
\hline
\end{tabular}

\section{Noordzee kustzone}

\begin{tabular}{|r|r|r|r|r|r|r|r|r|r|r|r|r|r|}
\hline & Jan & Feb & Maa & Apr & Mei & Jun & Jul & Aug & Sep & Okt & Nov & Dec \\
\hline 2013 & 6018 & 2501 & 6808 & 12508 & 11462 & 11451 & 14021 & 12311 & 11983 & 12680 & 9138 & 6623 \\
\hline 2014 & 6272 & 6584 & 12577 & 20040 & 15926 & 14300 & 17865 & 12096 & 15223 & 11853 & 11642 & 5879 \\
\hline 2015 & 5361 & 4268 & 7689 & 8312 & 3106 & 7214 & 12500 & 16496 & 14952 & 18515 & 10798 & 11657 \\
\hline 2016 & 8595 & 2566 & 5229 & 6289 & 6052 & 12126 & 14770 & 16990 & 21772 & 20431 & 20684 & 15350 \\
\hline 2017 & 14347 & 7344 & 7715 & 3950 & 8296 & 10906 & 6238 & 4471 & 11929 & 6877 & 5411 & 2729 \\
\hline 2018 & 4170 & 2500 & 3445 & 5128 & 3886 & 9789 & 23237 & 17437 & 17421 & 9239 & 9944 & 6070 \\
\hline 2019 & 6313 & 5632 & 5349 & 8189 & 5068 & 5845 & 7233 & 7003 & 10642 & 16155 & 13129 & 8343 \\
\hline 2020 & 6561 & 1636 & 9437 & 5194 & 4538 & 12928 & 14389 & 15994 & 17547 & 16945 & 12653 & 9056 \\
\hline
\end{tabular}

\section{Voordelta}

\begin{tabular}{l|r|r|r|r|r|r|r|r|r|r|r|r|}
\hline 2013 & Jan & Feb & Maa & Apr & Mei & Jun & Jul & Aug & Sep & Okt & Nov & Dec \\
\hline 2014 & 942 & 204 & 875 & 2097 & 2053 & 1575 & 1385 & 766 & 1118 & 2249 & 3050 & 1701 \\
\hline 2015 & 1379 & 340 & 844 & 1139 & 744 & 572 & 607 & 1885 & 5137 & 5227 & 4236 & 3456 \\
\hline 2016 & 2409 & 887 & 331 & 209 & 1380 & 3029 & 805 & 2296 & 2689 & 3990 & 6669 & 3373 \\
\hline 2017 & 2458 & 870 & 664 & 273 & 1115 & 1141 & 975 & 956 & 3770 & 9289 & 5454 & 2684 \\
\hline 2018 & 1153 & 306 & 65 & 53 & 1242 & 1042 & 197 & 2066 & 3293 & 2324 & 2483 & 2188 \\
\hline 2019 & 1644 & 547 & 597 & 1063 & 1011 & 730 & 796 & 693 & 820 & 3959 & 3446 & 1804 \\
\hline 2020 & 1055 & 116 & 919 & 1197 & 1626 & 1067 & 1446 & 644 & 2059 & 4263 & 3474 & 944 \\
\hline
\end{tabular}


Vlakte van de Raan

\begin{tabular}{|r|r|r|r|r|r|r|r|r|r|r|r|r|r|}
\hline & Jan & Feb & Maa & Apr & Mei & Jun & Jul & Aug & Sep & Okt & Nov & Dec \\
\hline 2013 & 57 & 22 & 17 & 325 & 545 & 498 & 259 & 432 & 455 & 615 & 312 & 87 \\
\hline 2014 & 48 & 10 & 5 & 0 & 23 & 279 & 449 & 380 & 928 & 393 & 408 & 354 \\
\hline 2015 & 110 & 0 & 29 & 215 & 59 & 60 & 50 & 1049 & 962 & 533 & 226 & 350 \\
\hline 2016 & 165 & 57 & 37 & 44 & 163 & 219 & 209 & 1073 & 957 & 907 & 546 & 283 \\
\hline 2017 & 150 & 40 & 445 & 99 & 228 & 67 & 981 & 439 & 1238 & 478 & 234 & 114 \\
\hline 2018 & 104 & 1 & 9 & 107 & 587 & 224 & 18 & 584 & 1267 & 1161 & 241 & 13 \\
\hline 2019 & 12 & 2 & 30 & 272 & 53 & 159 & 268 & 371 & 981 & 1113 & 426 & 99 \\
\hline 2020 & 66 & 0 & 575 & 254 & 97 & 364 & 752 & 536 & 1370 & 533 & 516 & 225 \\
\hline
\end{tabular}

\section{Waddenzee}

\begin{tabular}{|r|r|r|r|r|r|r|r|r|r|r|r|r|r|}
\hline & Jan & Feb & Maa & Apr & Mei & Jun & Jul & Aug & Sep & Okt & Nov & Dec \\
\hline 2013 & 1313 & 474 & 842 & 4616 & 8540 & 10145 & 13307 & 11196 & 11765 & 12781 & 9759 & 3956 \\
\hline 2014 & 3572 & 2150 & 5441 & 6609 & 9119 & 10913 & 8733 & 7120 & 7405 & 6229 & 6078 & 6400 \\
\hline 2015 & 5120 & 2452 & 3437 & 6523 & 6417 & 8248 & 7916 & 8732 & 11636 & 10449 & 11893 & 9569 \\
\hline 2016 & 8233 & 2660 & 4663 & 6329 & 10029 & 12454 & 9722 & 8142 & 7784 & 9950 & 12742 & 8110 \\
\hline 2017 & 6499 & 2447 & 5216 & 7186 & 12072 & 9417 & 10143 & 7717 & 9347 & 11522 & 12581 & 7731 \\
\hline 2018 & 7811 & 3101 & 1176 & 5509 & 12121 & 12563 & 11082 & 5865 & 8339 & 8580 & 4090 & 2526 \\
\hline 2019 & 3243 & 2332 & 3040 & 4270 & 4015 & 4393 & 4715 & 2478 & 5692 & 7649 & 9291 & 6326 \\
\hline 2020 & 7007 & 2650 & 5457 & 4104 & 3180 & 9643 & 9266 & 6166 & 7371 & 9925 & 11562 & 8486 \\
\hline
\end{tabular}


Wageningen Marine Research

T: $+31(0) 317480900$

E: marine-research@wur.nl

www.wur.nl/marine-research

Bezoekers adres:

- Ankerpark 271781 AG Den Helder

- Korringaweg 7, 4401 NT Yerseke

- Haringkade 1, 1976 CP IJmuiden
Wageningen Marine Research levert met kennis, onafhankelijk wetenschappelijk onderzoek en advies een wezenlijke bijdrage aan een duurzamer, zorgvuldiger beheer, gebruik en bescherming van de natuurlijke rijkdommen in zee-, kust- en zoetwatergebieden.
Wageningen Marine Research is onderdeel van Wageningen University \& Research. Wageningen University \& Research is het samenwerkingsverband tussen Wageningen University en Stichting Wageningen Research en heeft als missie: 'To explore the potential of nature to improve the quality of life' 